\section{Hazardous alcohol use among transwomen in a Brazilian city}

\section{Consumo excessivo de álcool entre mulheres transgênero numa cidade brasileira}

\section{Consumo excesivo de alcohol entre mujeres transexuales en una ciudad brasileña}

Florence Kerr-Corrêa 1

Francisco Marto Leal Pinheiro Júnior 2

Telma Alves Martins 3

Daniel Lucas da Conceição Costa 4

Raimunda Hermelinda Maia Macena 2

Rosa Maria Salani Mota 5

Marcelle Yumi Yaegaschi 1

Kalina Livia Lopes Carneiro 2

Carl Kendall 6

Ligia Regina Franco Sansigolo Kerr 2

\begin{abstract}
There is a lack of information about alcohol use by transgender women. We estimated the prevalence of dangerous alcohol use in the last 12 months by transgender women, who are known as travestis in Brazil, and we identified the associated risk factors. Three hundred travestis were recruited using Respondent Driving Sampling (RDS). We applied the Alcohol Use Disorders Identification Test (AUDIT). We controlled the sample by applying a weight to each interviewee. Three quarters (74.2\%) of travestis were regular drinkers, half (48.7\%) scored over eight in the AUDIT and 14.8\% scored over 20. The risk factors for alcohol use were: aged over 24, low income and unprotected sex. The dangerous use of alcohol is prevalent among travestis. Given that this group has a greater risk of HIV infection and transmission, and that the dangerous use of alcohol was associated with unsafe sex, specific intervention strategies are required.
\end{abstract}

Alcohol Drinking; Transgender Persons; Transvestism

\section{Correspondence}

F. M. L. Pinheiro Júnior

Departamento de Saúde Comunitária, Faculdade de Medicina, Universidade Federal do Ceará.

Rua Professor Costa Mendes 1608, $5^{\circ}$ andar, Fortaleza, CE 60430-140, Brasil.

martolp@gmail.com

1 Faculdade de Medicina, Universidade Estadual Paulista "Julio de Mesquita Filho", Botucatu, Brasil.

2 Faculdade de Medicina, Universidade Federal do Ceará, Fortaleza, Brasil.

3 Secretaria de Saúde do Estado, Fortaleza, Brasil.

4 Instituto de Psiquiatria, Universidade de São Paulo, São Paulo, Brasil.

5 Departamento de Estatística e Matemática Aplicada,

Universidade Federal do Ceará, Fortaleza, Brasil.

6 School of Public Health and Tropical Medicine, Tulane

University, New Orleans, U.S.A. 


\section{Introduction}

Transgender women (or transwomen) have been shown to be highly vulnerable both to AIDS, with high HIV prevalence, and substantial alcohol use ${ }^{1}$. Although sometimes controversial, the association between alcohol use and sexual risk behavior has been well reported 2 .

Recent studies demonstrated rates of alcoholism among transgender people ranging from $58 \%$ to $85 \%$ 3,4. Gay men present lower rates of alcohol abstinence compared to heterosexual men (14\% versus $34 \%$, respectively) 5 . Additionally, there are higher percentages of moderate drinkers (71\% versus $57 \%$, respectively) and alcohol-related problems (23\% versus $12 \%$, respectively) among gay men and lesbians compared to the general population 6 . One possible explanation for these phenomena would be the stress experienced by LGBT (lesbian, gay, bisexual, and transgender) people due to homophobia and discrimination 7 . The use of alcohol and other psychoactive substances may be a coping mechanism activated by homosexual stigma 8 . Another possible factor associated with increased prevalence of substance use would be a history of violence and victimization - physical, emotional or sexual - in childhood 9 . Additionally, some studies suggest that rates of alcohol use among homosexuals decrease less with increasing age than in the general population 1,10 .

The aim of this study was to assess prevalence of alcohol use and risk factors associated with this use among a subgroup of men who have sex with men (MSM), transgendered male-to-female individuals, or transwomen, identifying themselves as travestis in Fortaleza, Ceará State, Brazil.

The term travesti translates literally as transvestite in English, a term with derogatory connotations. However, we decided to use the local term because it remains the most widely used identity category to refer to this population in Brazil 11 and was the most used by the women in our study themselves.

We demonstrate here that travestis may be at increased risk of discrimination and violence, and many are sex workers, further adding to the abuse of alcohol and accompanying risks.

\section{Materials and methods}

\section{Study design}

This is a cross-sectional study conducted between August and December 2008. The sample, recruited using Respondent Driven Sampling (RDS), consisted of 304 self-identified travestis living in the city of Fortaleza that reported having any sexual contact with another man in the six months preceding the survey.

RDS is a systematic and operationally rigorous sampling method that is widely used and theoretically makes it possible to calculate indicators adjusted for recruitment bias in populations that are difficult to access but connected to each other through a social network 12,13, as in the case of travestis. The Brazilian Ministry of Health adopted RDS for biological and behavioral surveillance for MSM. Comparing RDS to Time Location Sampling (TLS), another sampling method that may be used for hard-to-reach populations, RDS identified many more MSM in Fortaleza of low socioeconomic status 1,14 , a population with more public health relevance, and an outcome observed in other studies 14 . For these and other reasons, the Brazilian government 15 and Centers for Disease Control and Prevention (CDC) 16, in the United States, recommend RDS as the method of choice for biological and behavioral and surveillance among key populations.

\section{Setting}

Fortaleza is a city in the Northeast of Brazil, one of the poorest regions of the country. About $30 \%$ of the population is considered low income (earning less than half the minimum wage) 17. Fortaleza has been identified as one of the main Brazilian cities for sex tourism 18, including the use of travesti sex workers.

In 2013, Fortaleza recorded 26.5 AIDS cases per 100,000 inhabitants 19. The AIDS epidemic in the northeast is growing, reflecting a situation of high concern, while AIDS in the South is heading 
towards a stabilization of the epidemic by 2019 20. In addition, all research on HIV prevention measures in the general population shows that indicators for condom use and knowledge about AIDS are lower in the Northeast 21.

This study was conducted with the non-governmental organization (NGO), ATRAC (Travestis Association of Ceará).

\section{Participants}

Three hundred four travestis were recruited using RDS. The choice of seeds, incentives and study site were based on formative research conducted in ATRAC with nine travestis. During these interviews we discussed the site of the study, criteria for recruiting interviewees (travestis, women or MSM only), and levels of incentives. Eight seeds, all travestis, representing different social classes, were selected to initiate the RDS study. Several seeds proved to be non-productive, and recruitment proceeded very slowly, so we added an additional six seeds. These seeds were selected with the same criteria, but we selected two additional seeds with a higher socioeconomic status because recruitment among this group was even slower. Each recruiter received three coupons to distribute, and this procedure was repeated until the sample size was achieved. These coupons were to be given to other travestis who were known to the recruiter but were not their partner, a relative or a close friend. As we neared completion of the study we reduced to two the number of coupons to be distributed. Each participant who completed the questionnaire received as an incentive a coupon for the purchase of food that could be redeemed at supermarkets with a value of about US\$ 6. For each respondent they successfully recruited to the study, they received an incentive of about US\$ 3 .

\section{Variables}

A semi-structured questionnaire was administered collecting information on the following socioeconomic and demographic variables: age, race/ethnicity, education, occupation, income, religion and social class. Social class assignments used the Brazil Economic Classification Criteria 22.

The social context indicators included residence, family support, NGO participation; violence and discrimination; while indicators for sexual behavior and knowledge of HIV transmission included: sexual debut, current sexual behavior by partner type and HIV testing. Unprotected sex was defined as those who reported no condom use with any partner except for oral sex.

For knowledge of the transmission of AIDS, we asked five questions: (a) if sex with only a single, faithful, non-infected partner reduced transmission; (b) if the use of condoms reduced the risk of HIV transmission; (c) if an HIV infected person can look healthy; (d) if HIV can be transmitted by mosquitoes; and (e) if HIV can be transmitted through the sharing of food. We classified respondents on a three point scale: (a) 5 correct responses, (b) correct answers to the first 3 questions; and (c) low knowledge, failure on any of the first three questions.

The use of illicit drugs in the past six months was defined as using at least one illicit drug or prescription use without a prescription.

The Alcohol Use Disorders Identification Test (AUDIT) was prepared for the World Health Organization (WHO) by Babor et al. ${ }^{23}$. The tool was translated and validated in Brazil by Lima et al. ${ }^{24}$. The score ranges from 0 to 40 . An individual is classified as abstinent or low-risk (0-7 points); risky (8-15 points); high-risk or hazardous consumption (16-19 points) and probable dependence (20 or more points) 25 . A dependent variable was created and named "hazardous alcohol use". It was defined as 1 if the AUDIT score was equal to or greater than 8 and zero if less than 8 .

Heavy drinking was defined as the ingestion of five or more drinks in a row for men and four drinks for women $26,27,28$.

\section{Statistical methods}

The data were analyzed in RDSAT 5.6 (Volz E, Wejnert C, Degani I, Heckathorn DD. Cornell University, Ithaca, USA) to adjust for individual network size and differential recruitment. Weights were calculated for outcome variables and added to the database. Dates were exported to Stata 10.0 (Stata- 
Corp LP, College Station, USA) for univariate, bivariate and multivariate analyses. Alcohol abuse was the dependent variable. Variables that have a 0.20 significance level in the bivariate analysis, or are identified in the literature as relevant, were used in the logistic regression model to calculate their independent effect. Odds ratio (OR) and 95\% confidence intervals (95\%CI) were calculated. Possible confounders and modifiers were explored. In the logistic regression, $\mathrm{p}<0.05$ was considered significant; and alcohol abuse was the dependent variable.

\section{Ethical considerations}

This study was approved by the Research Ethics Committee of the Ceará Federal University, Brazil. All respondents were consented and assured confidentiality. All were offered rapid HIV testing and counseling. Respondents could remain in the study if they refused testing. Only four respondents agreed to be tested, although 70\% reported previous tests and a willingness to report results.

\section{Results}

All the transwomen in the study are in transition, taking female hormones and surgically augmenting their breasts. None had sexual reassignment surgery. 24 respondents (7.9\%) defined themselves as transsexual.

Characteristics of the population are described in Table 1 . The majority of them were older than 24 (51.8\%); with racial classification "pardo", (roughly translating as "mixed race"; 59.8\%); 41\% had not completed elementary education, and $60 \%$ had not completed high school. Sixty-six percent identified as Catholics, a relatively large minority (17\%) as a member of an Afro-Brazilian religion, although with low participation: $72 \%$ of the population overall did not attend church as frequently as once a week. With respect to income, 38\% earned less than the monthly minimum salary (approximately US\$ 540 in 2009), and 89\% less than four times the minimum wage. A plurality (48\%) identified themselves as social class $\mathrm{C}$, midway in the class categorization, but $38 \%$ identified themselves as social classes D or E, the lowest. Almost half (49\%) live with their partners or family. Overall, for the entire sample, $62 \%$ claim that their families fully support their sexual and gender orientation. The population was active in NGOs, $81 \%$ claiming participation, and 77\% reporting that they felt support from these organizations. With respect to violence and discrimination, $62 \%$ reported an act of violence against them in the last six months, and $85 \%$ reported an act of discrimination.

\section{Data regarding the use of alcohol}

Three-quarters (74.2\%) of the sample reported alcohol use in the last year. Of these, half (48.2\%) of the participants reported hazardous alcohol use, indicated by an AUDIT score equal to or greater than eight (average $8.85 \pm 8.72$ ). Almost half (46.4\%) reported episodic heavy drinking one or more times per month in the last year. An AUDIT score above 20, indicating possible dependence, was reported by $14.8 \%$ of the sample (Table 2 ).

\section{Multivariate analysis}

Table 3 shows the variables associated with an AUDIT score equal to or greater than eight, among travestis. Socioeconomic and demographic variables that correlated with increased risk of the outcome were: age over 24 years $(\mathrm{OR}=8.81, \mathrm{p}<0.001)$, monthly income below one minimum wage $(\mathrm{OR}=$ 5.109, $\mathrm{p}=0.002$, about US\$ 300) and between one to four minimum wages $(\mathrm{OR}=2.837, \mathrm{p}=0.017)$, black race $(\mathrm{OR}=3.667, \mathrm{p}=0.006)$ and living with family $(\mathrm{OR}=2.188, \mathrm{p}=0.037)$. With regard to other risky behaviors: prostitution $(\mathrm{OR}=3.472, \mathrm{p}=0.008)$, use of illicit drugs in the six months preceding the survey $(\mathrm{OR}=2.575, \mathrm{p}=0.003)$ and unprotected $\operatorname{sex}(\mathrm{OR}=3.207, \mathrm{p}<0.001)$ were associated with hazardous alcohol use.

Table 4 indicates that almost half of low-income travestis $52.6 \%$ of those receiving less than the monthly minimum wage and $53.8 \%$ of those receiving between one and four minimum salaries per 


\section{Table 1}

Socio-demographic and social context of transwomen living in Fortaleza, Ceará State, Brazil.

\begin{tabular}{|c|c|c|c|}
\hline \multirow[t]{2}{*}{ Socio-demographic characteristics } & \multirow{2}{*}{$\begin{array}{c}\text { Crude } \\
\%\end{array}$} & \multicolumn{2}{|c|}{ Adjusted * } \\
\hline & & $\%$ & $95 \% \mathrm{Cl}$ \\
\hline \multicolumn{4}{|l|}{ Race $[n=302]$} \\
\hline White & 26 & 23 & $17-30$ \\
\hline Black & 13 & 17 & $11-24$ \\
\hline “Pardo" (mixed) & 60 & 59 & $50-66$ \\
\hline Other & 2 & 1 & $0-3$ \\
\hline \multicolumn{4}{|l|}{ Age (years) $[n=304]$} \\
\hline$<18$ & 22 & 29 & $20-39$ \\
\hline $18-24$ & 26 & 20 & $14-26$ \\
\hline$>24$ & 52 & 51 & $41-61$ \\
\hline \multicolumn{4}{|l|}{ Education [n = 304] } \\
\hline Illiterate/-3rd grade & 9 & 8 & $4-13$ \\
\hline $4^{\text {th }}$ to $8^{\text {th }}$ grade & 35 & 33 & $25-40$ \\
\hline Complete primary & 13 & 14 & $9-20$ \\
\hline Incomplete secondary & 14 & 18 & $11-25$ \\
\hline Complete secondary or some university & 30 & 26 & $19-34$ \\
\hline \multicolumn{4}{|l|}{ Religion $[n=303]$} \\
\hline Catholic & 72 & 66 & $58-74$ \\
\hline Protestant/Evangelical & 6 & 9 & $4-16$ \\
\hline Afro-Brazilian & 15 & 17 & $11-24$ \\
\hline Other & 7 & 8 & $3-12$ \\
\hline \multicolumn{4}{|l|}{ Social class [n = 304] } \\
\hline $\mathrm{A} / \mathrm{B}$ & 38 & 38 & $30-47$ \\
\hline $\mathrm{C}$ & 47 & 48 & $39-56$ \\
\hline $\mathrm{D} / \mathrm{E}$ & 15 & 14 & $9-20$ \\
\hline \multicolumn{4}{|l|}{ Employment [n = 301] } \\
\hline Employed full-time & 20 & 21 & $15-30$ \\
\hline Employed part-time & 31 & 26 & $20-34$ \\
\hline Self-employed & 18 & 20 & $12-29$ \\
\hline Unemployed & 9 & 11 & $6-17$ \\
\hline Student & 3 & 3 & $0-5$ \\
\hline Retired & 20 & 9 & $11-25$ \\
\hline \multicolumn{4}{|l|}{ Income (minimum wage) [n = 298] } \\
\hline$<1$ & 35 & 37 & $27-46$ \\
\hline $1-4$ & 54 & 52 & $43-60$ \\
\hline$>4$ & 11 & 11 & $6-18$ \\
\hline \multicolumn{4}{|l|}{ Residence $[n=304]$} \\
\hline Lives alone & 19 & 23 & $25-31$ \\
\hline Lives with partner & 6 & 6 & $3-10$ \\
\hline Family & 45 & 49 & $40-58$ \\
\hline Lives with madam/friends & 30 & 22 & $14-31$ \\
\hline \multicolumn{4}{|l|}{ Family response $[n=298]$} \\
\hline Fully supports/Supports financially & 66 & 63 & $54-71$ \\
\hline Supports with restrictions & 30 & 34 & $26-43$ \\
\hline Disapproves & 4 & 3 & $0-5$ \\
\hline \multicolumn{4}{|l|}{ Ever resided in another state/country [ $n=303]$} \\
\hline Yes & 35 & 32 & $24-40$ \\
\hline No & 65 & 68 & $60-76$ \\
\hline Victim of violence [ $n=296]$ & 65 & 61 & $52-70$ \\
\hline Victim of homophobia [ $n=304]$ & 89 & 91 & $86-95$ \\
\hline
\end{tabular}

95\%Cl: 95\% confidence interval.

* Adjusted with RDS Analysis Tool (RDSAT) 5.6 (Volz E, Wejnert C, Degani I, Heckathorn DD. Cornell University, Ithaca, USA). 
Table 2

Alcohol use by transwomen in the last year. Fortaleza, Ceará State, Brazil.

\begin{tabular}{|c|c|c|c|c|}
\hline Variables & $\mathbf{n}$ & $\%$ crude & $\%$ adjusted * & $95 \% \mathrm{Cl}$ \\
\hline \multicolumn{5}{|c|}{ How often do you have a drink containing alcohol? } \\
\hline Never & 81 & 26.6 & 25.8 & 19.1-33.8 \\
\hline Monthly or less & 68 & 22.4 & 25.0 & 18.4-33.6 \\
\hline 2-4 times a month & 83 & 27.3 & 24.8 & $17.6-31.8$ \\
\hline 2-3 times a week & 56 & 18.4 & 22.1 & $14.3-28.5$ \\
\hline 4 or more times a week & 16 & 5.3 & 2.4 & $1.1-4.2$ \\
\hline \multicolumn{5}{|c|}{$\begin{array}{l}\text { How many standard drinks containing alcohol do you have on a typical day when } \\
\text { drinking? }\end{array}$} \\
\hline Do not drink or 1 drink & 119 & 39.3 & 35.4 & $27.6-44.2$ \\
\hline 2 to 3 drinks & 35 & 11.6 & 13.4 & 7.9-20.2 \\
\hline 4 to 5 drinks & 33 & 10.9 & 9.8 & $5.8-14.3$ \\
\hline 6 to 7 drinks & 22 & 7.3 & 5.6 & 3.0-9.7 \\
\hline 4 to 8 drinks or more & 94 & 31.0 & 35.7 & $27.1-42.9$ \\
\hline \multicolumn{5}{|c|}{ How often do you have five or more drinks on one occasion? } \\
\hline Never & 122 & 40.3 & 40.4 & $32.6-48.9$ \\
\hline Less than monthly & 41 & 13.5 & 13.2 & $8.5-19.6$ \\
\hline Monthly & 33 & 10.9 & 12.1 & 7.0-19.2 \\
\hline Weekly & 92 & 30.4 & 31.4 & 22.4-38.2 \\
\hline Daily or almost daily & 15 & 5.0 & 2.9 & $1.3-5.0$ \\
\hline \multicolumn{5}{|c|}{$\begin{array}{l}\text { How often during the last year have you found that you were not able to stop drinking } \\
\text { once you had started? }\end{array}$} \\
\hline Never & 240 & 79.2 & 76.8 & $70.5-85.0$ \\
\hline Less than monthly & 18 & 5.9 & 6.9 & $3.0-11.5$ \\
\hline Monthly & 11 & 3.6 & 3.8 & $0.7-6.7$ \\
\hline Weekly & 31 & 10.2 & 11.5 & $6.4-16.8$ \\
\hline Daily or almost daily & 3 & 1.0 & 1.0 & $0.1-2.4$ \\
\hline \multicolumn{5}{|c|}{$\begin{array}{l}\text { How often during the last year have you failed to do what was normally expected from } \\
\text { you because of drinking? }\end{array}$} \\
\hline Never & 228 & 75.2 & 73.5 & $65.1-80.9$ \\
\hline Less than monthly & 26 & 8.6 & 8.5 & 4.1-11.5 \\
\hline Monthly & 21 & 6.9 & 9.3 & $5.0-15.6$ \\
\hline Weekly & 26 & 8.6 & 8.5 & 4.7-14.2 \\
\hline Daily or almost daily & 2 & 0.7 & 0.2 & $0.1-0.5$ \\
\hline \multicolumn{5}{|c|}{$\begin{array}{l}\text { How often during the last year have you needed a first drink in the morning to get } \\
\text { yourself going after a heavy drinking session? }\end{array}$} \\
\hline Never & 261 & 86.1 & 83.2 & $76.9-90.0$ \\
\hline Less than monthly & 14 & 4.6 & 6.4 & $2.0-10.5$ \\
\hline Monthly & 16 & 5.3 & 5.9 & $2.2-11.3$ \\
\hline Weekly & 8 & 2.6 & 4.1 & $0.7-8.6$ \\
\hline Daily or almost daily & 4 & 1.3 & 0.4 & $0.1-1.2$ \\
\hline \multicolumn{5}{|c|}{$\begin{array}{l}\text { How often during the last year have you had a feeling of guilt or remorse after } \\
\text { drinking? }\end{array}$} \\
\hline Never & 214 & 70.6 & 68.0 & $60.3-76.3$ \\
\hline Less than monthly & 34 & 11.2 & 11.7 & 6.1-16.4 \\
\hline Monthly & 24 & 7.9 & 11.7 & $6.0-19.7$ \\
\hline Weekly & 27 & 8.9 & 7.5 & $3.6-11.7$ \\
\hline Daily or almost daily & 4 & 1.3 & 1.1 & $0.1-3.2$ \\
\hline
\end{tabular}

(continues) 
Table 2 (continued)

\begin{tabular}{|c|c|c|c|c|}
\hline Variables & $\mathbf{n}$ & $\%$ crude & $\%$ adjusted * & $95 \% \mathrm{Cl}$ \\
\hline \multicolumn{5}{|c|}{$\begin{array}{l}\text { How often during the last year have you been unable to remember what happened } \\
\text { the night before because you had been drinking? }\end{array}$} \\
\hline Never & 232 & 76.6 & 72.9 & $65.4-80.8$ \\
\hline Less than monthly & 33 & 10.9 & 14.4 & 8.0-19.4 \\
\hline Monthly & 18 & 5.9 & 7.4 & 3.9-12.2 \\
\hline Weekly & 19 & 6.3 & 5.0 & $2.4-8.2$ \\
\hline Daily or almost daily & 1 & 0.3 & 0.3 & - \\
\hline \multicolumn{5}{|c|}{ Have you or someone else been injured as a result of your drinking? } \\
\hline No & 230 & 75.9 & 77.7 & $71.7-84.9$ \\
\hline Yes, but not in the past year & 27 & 8.9 & 8.5 & 4.8-13.3 \\
\hline Yes, during the past year & 46 & 15.2 & 13.8 & 7.6-18.9 \\
\hline \multicolumn{5}{|c|}{$\begin{array}{l}\text { Has a relative or friend or doctor or other health worker been concerned about your } \\
\text { drinking or suggested you cut down? }\end{array}$} \\
\hline No & 217 & 71.6 & 69.5 & $61.8-78.3$ \\
\hline Yes, but not in the past year & 22 & 7.3 & 8.9 & $4.0-13.2$ \\
\hline Yes, during the past year & 64 & 21.1 & 21.6 & $14.8-28.4$ \\
\hline \multicolumn{5}{|l|}{ AUDIT score } \\
\hline $0-7$ & 155 & 51.2 & 48.8 & $40.7-58.5$ \\
\hline $8-15$ & 81 & 26.7 & 28.5 & $20.7-36.7$ \\
\hline $16-19$ & 23 & 7.6 & 7.9 & 4.1-13.6 \\
\hline $20-40$ & 44 & 14.5 & 14.8 & 8.3-19.1 \\
\hline AUDIT score $\geq 8$ & 148 & 48.8 & 48.2 & $40.2-58.4$ \\
\hline
\end{tabular}

95\%Cl: 95\% confidence interval; AUDIT: Alcohol Use Disorders Identification Test.

* Adjusted for Respondent Driving Sampling (RDS).

\section{Table 3}

Logistic regression for hazardous alcohol use among transwomen. Fortaleza, Ceará State, Brazil.

\begin{tabular}{lc}
\hline Variables & OR (95\% CI) \\
\hline $\begin{array}{l}\text { Age (years) } \\
18-24\end{array}$ & $1.751(0.718-4.267)$ \\
$>24$ & $8.810(3.905-19.874)$ \\
Monthly income (minimum wages) & $5.109(1.856-14.058)$ \\
$<1$ & $2.837(1.209-6.654)$ \\
$1-4$ & \\
$\quad$ Race & $3.667(1.453-9.252)$ \\
Black & $1.190(0.602-2.353)$ \\
“Pardo" (Mixed) & \\
Residence status & $1.310(0.578-2.971)$ \\
Alone & $0.421(0.099-1.791)$ \\
With partner & $2.188(1.050-4.562)$ \\
Family & $3.472(1.390-8.670)$ \\
Have ever received money or gifts for sex? & $2.575(1.388-4.778)$ \\
Used illicit drugs during the last 6 months? & $3.207(1.710-6.016)$ \\
Unprotected sex (excluding oral sex)? &
\end{tabular}

95\%Cl: 95\% confidence interval; OR: odds ratio. 
Frequency of hazardous alcohol use among transwomen, indicated by Alcohol Use Disorders Identification Test (AUDIT) score $\geq 8$, by selected variables. Fortaleza, Ceará State, Brazil.

\begin{tabular}{|c|c|c|}
\hline \multirow[t]{2}{*}{ Variables } & \multicolumn{2}{|c|}{ AUDIT score $\geq 8$} \\
\hline & $\%$ & $95 \% \mathrm{Cl}$ \\
\hline \multicolumn{3}{|l|}{ Age (years) } \\
\hline$<18$ & 35.5 & $19.5-52.2$ \\
\hline $18-24$ & 35.0 & $23.5-50.2$ \\
\hline$>24$ & 64.1 & $51.0-74.9$ \\
\hline \multicolumn{3}{|l|}{ Income (minimum wages) } \\
\hline$<1$ & 52.6 & $38.1-68.3$ \\
\hline $1-4$ & 53.8 & $41.2-66.2$ \\
\hline$\geq 4$ & 34.2 & 10.4-53.3 \\
\hline \multicolumn{3}{|l|}{ Residence status } \\
\hline Alone & 60.4 & $38.7-80.2$ \\
\hline With partner & 32.7 & $9.3-61.3$ \\
\hline Family & 54.8 & $42.5-66.5$ \\
\hline Friend(s)/"Cafetina" (Madam) & 41.3 & $27.3-58.3$ \\
\hline \multicolumn{3}{|l|}{ Race } \\
\hline White & 47.7 & $30.7-62.9$ \\
\hline Black & 68.2 & $45.9-87.1$ \\
\hline “Pardo" (mixed) & 48.7 & $37.0-59.0$ \\
\hline \multicolumn{3}{|c|}{ Have ever received money or gifts for sex? } \\
\hline Yes & 55.1 & $44.2-63.2$ \\
\hline No & 35.2 & $17.6-58.1$ \\
\hline \multicolumn{3}{|c|}{ Used illicit drugs during the last 6 months? } \\
\hline No & 43.7 & $33.2-54.4$ \\
\hline Yes & 64.6 & 48.4-75.7 \\
\hline \multicolumn{3}{|c|}{ Unprotected sex (excluding oral sex)? } \\
\hline No & 49.9 & $34.0-61.4$ \\
\hline Yes & 57.3 & $44.5-68.3$ \\
\hline
\end{tabular}

95\%Cl: 95\% confidence interval.

month), approximately two-thirds (64.1\%) of participants over the age of 24 and $60.4 \%$ self-reporting black race had an AUDIT score above eight. In addition, 55.1\% practicing prostitution, $64.6 \%$ of those using illicit drugs in the six months preceding the survey, and $57.3 \%$ of those who practice unprotected sex also reported higher AUDIT scores.

\section{Discussion}

The present study showed that almost three-quarters (74.2\%) of the sample reported alcohol use in the last year. This rate is higher than that found by Laranjeira et al. 29 in a general population study in Brazil, who reported alcohol use at least once in the last year in 50\% of the sample. As noted above, almost half (46.4\%) of respondents reported episodic heavy drinking one or more times per month last year. Laranjeira et al. 29 also reported lower levels (28\%) of episodic heavy drinking in the general population. Men reported a higher level of episodic heavy drinking than women: $40 \%$ of the male population reported this, while $18 \%$ of female respondents reported episodic heavy drinking at least once in the last year. 
The quantity of alcohol ingested in these episodes is enough to make many people intoxicated although other factors play an important role in the speed and degree of intoxication, such as gender, drinking on an empty stomach, or drinking too fast 30,31. This form of drinking is more often associated with a number of physical and mental problems 26 . Two types of problems, accidents and violence, deserve special attention in relation to episodic heavy drinking 32. Car accidents, falls, pedestrian accidents, and drowning are associated with episodic heavy drinking. Various kinds of interpersonal violence are also related to episodic heavy drinking such as homicide, robbery, domestic violence, physical assault, and sexual violence.

Another concern is the proportion of participants (14.8\%) with an AUDIT score above 20, indicating possible alcohol dependence. According to the Second Population-based Survey on the Use of Psychotropic Drugs in Brazil 33, the prevalence of alcohol dependence in the general population is 12.3\%. One should take into account the SAMHSA (Substance Abuse and Mental Health Services Administration) criteria for the classification of alcohol dependence, so this rate may be overestimated 34 . In a separate study that has not yet been published, we found that travestis with AUDIT scores above 20 test for HIV at higher rates than those below 20.

In summary, age over 24, low income, "pardo" race, living with the family, prostitution, use of illicit drugs in the previous six months of the study and the practice of unsafe sex were positively correlated with hazardous drinking among travestis in our study. In most countries, transgendered individuals have limited job opportunities and may have difficulty fitting into the formal sector of the economy, so that prostitution remains one of the few viable options 34,35,36. Independent of their transgendered status, sex workers constitute a risk group for HIV infection and other sexually transmitted diseases $37,38,39,40,41$.

In this population, the risk is even higher among those working in the street (versus those who work in a brothel), have sex with partners of unknown HIV serostatus, use condoms inconsistently, have low socioeconomic status, are homeless and are dependent on alcohol and drugs 42 . Factors related to increased risk of HIV infection among transgendered individuals include: unprotected sex, multiple sex partners, prostitution, use of injectable substances (drugs, hormones and silicone), social stigma and belonging to a racial or ethnic minority 42,43,44,45,46. The findings of this study show that travestis demonstrate many characteristics that put them at risk of HIV infection.

Travestis in our study reported hazardous alcohol use with greater frequency than the general population as they age. This finding is consistent with other studies 5,47 that found rates of alcohol use by MSM to decrease significantly less than the general population as age increases 10 .

For travestis, already vulnerable to unsafe sex due to stigma and discrimination, alcohol adds additional risk and continues throughout life. Despite the current global emphasis on illegal drugs, consumption of alcoholic beverages - due to prevalence and abuse - continues to be a central problem for public health. Besides direct physiological effects, consumption of alcohol affects sexual behavior, decreasing safe sex behaviors for a significant fraction of the population 48 .

\section{Study limitations}

Limitations of the study include those associated with self-report for both serostatus and behavior, and social acceptability biases for the report of drinking and behavior. We explored these potential biases, especially for reporting alcohol use and sexual behaviors in formative research and attempted to minimize these effects through instrument design and fieldworker training. Still, the biases are likely to minimize the effects we found. Given the high rates of drinking and other behaviors reported, these would only make the problems we report worse.

Another limitation of the study is the difficult access to this population with a strong gatekeeper, and the limited social environment that the transwomen here could recruit from. This may have overestimated the proportion of travestis participating in the study. Again, the effect of this would likely be to minimize the already quite substantial effects we report here. 


\section{Conclusions}

Hazardous alcohol use is prevalent among travestis in our study. While descriptive, the study opens a window on a range of likely reasons for this heavy drinking and their health consequences for travestis and the general population. Heavy drinking highlights a constellation of factors directly and indirectly involved in health: social and sexual vulnerability and high risk behaviors, stigma, discrimination and social isolation, mental health issues as cause and consequence, issues in transitioning, and limited access to open and travesti friendly health services among them that need to be addressed if the AIDS epidemic is to be controlled. In the past in Brazil, NGOs have played an important role in advocating for and delivering a wide range of services to key populations. In recent years the role of NGOs has been downplayed, and the role of the clinic elevated. While clinics have a unique role to play in clinical management, clinics are unlikely to be the perfect solution for this wide range of issues we discuss here, including alcohol and drug abuse; comprehensive programs that protect the rights and health of travestis are required, most probably led by civil society organizations.

We hope that the information provided through this survey can be used to better assist stakeholders to formulate policies and programs focusing on travestis, prevention and management of substance abuse, and the transmission of HIV/AIDS and other sexually transmitted diseases.

\section{Contributors}

F. Kerr-Corrêa contributed in the conception and planning of the study, data analysis and interpretation, writing of the article, critical and intellectual revision of the final version of the manuscript for publication, and agreement with all content. F. M. L. Pinheiro Júnior, D. L. C. Costa, M. Y. Yaegaschi and K. L. L. Carneiro participated in the data analysis and interpretation, writing of the article, approval of the final version for publication, and agreement with all content. T. A. Martins and R. H. M. Macena contributed in the conception and planning of the study, gathering and analysis of results, approval of the final version for publication, and agreement with all content. R. M. S. Mota collaborated in the data analysis and interpretation, approval of the final version for publication, and agreement with all content. C. Kendall and L. R. F. S. Kerr contributed to the conception and planning of the study, data analysis and interpretation, writing of the article, critical and intellectual revision of the final version of the manuscript for publication, and agreement with all content.

\section{Acknowledgments}

The authors wish to thank the Travestis Association of Ceará (ATRAC) for supporting the research, and the Brazilian Ministry of Health (Department of STD/AIDS and Viral Hepatitis). 


\section{References}

1. Reback C, Fletcher JB. HIV prevalence, substance use, and sexual risk behaviors among transgender women recruited through outreach. AIDS Behav 2014; 18:1359-67.

2. Hoffman BR. The interaction of drug use, sex work, and HIV among transgender women. Subst Use Misuse 2014; 49:1049-53.

3. Nuttbrock L, Bockting W, Rosenblum A, Hwahng S, Mason M, Macri M, et al. Gender abuse, depressive symptoms and substance use among transgender women: a 3-year prospective study. Am J Public Health 2014; 104: 2199-206.

4. Santos GM, Rapues J, Wilson EC, Macias O, Packer T, Colfax G, et al. Alcohol and substance use among transgender women in San Francisco: prevalence and association with human immunodeficiency virus infection. Drug Alcohol Rev 2014; 33:287-95.

5. Drabble L, Midanik LT, Trocki K. Reports of alcohol consumption and alcohol-related problems among homosexual, bisexual and heterosexual respondents: results from the 2000 National Alcohol Survey. J Stud Alcohol 2005; 66:111-20.

6. McKirnan DJ, Peterson PL. Alcohol and drug use among homosexual men and women: epidemiology and population characteristics. Addict Behav 1989; 14:545-53.

7. Hughes T, Eliason M. Substance use and abuse in lesbian, gay, bisexual and transgender populations. J Prim Prev 2002; 22:263-98.

8. Bruce D, Ramirez-Valles J, Campbell RT. Stigmatization, substance use, and sexual risk behavior among latino gay and bisexual men and transgender persons. J Drug Issues 2008; 38:235-60.

9. Tucci AM, Kerr-Corrêa F, Souza-Formigoni ML. Childhood trauma in substance use disorder and depression: an analysis by gender among a Brazilian clinical sample. Child Abuse Negl 2010; 34:95-104.

10. Wilsnack R, Wilsnack S. Gender and alcohol individual and social perspectives. Piscataway: Rutgers Center of Alcohol Studies; 1997.

11. Carvalho M, Carrara S. Em direção a um futuro trans? Contribuição para a história do movimento de travestis e transexuais no Brasil. Sex Salud Soc (Rio J.) 2013; 14:319-51.

12. Heckathorn DD. Respondent-driven sampling: a new approach to the study of hidden populations. Soc Probl 1997; 44:174-99.

13. Kendall C, Kerr LR, Gondim RC, Werneck GL, Macena RH, Pontes MK, et al. An empirical comparison of respondent-driven sampling, time location sampling, and snowball sampling for behavioral surveillance in men who have sex with men, Fortaleza, Brazil. AIDS Behav 2008; 12(4 Suppl):97-104.

14. Wei C, McFarland W, Colfax GN, Fuqua V, Raymond HF. Reaching black men who have sex with men: a comparison between respondent-driven sampling and time-location sampling. Sex Transm Infect 2012; 88:622-6.
15. Lansky A, Abdul-Quader AS, Cribbin M, Hall T, Finlayson TJ, Garfein RS, et al. Developing an HIV behavioral surveillance system for injecting drug users: the National HIV Behavioral Surveillance System. Public Health Rep 2007; 122(1 Suppl):48-55

16. Barbosa Júnior A, Pascom AR, Szwarcwald CL, Kendall C, McFarland W. Transfer of sampling methods for studies on most-at-risk populations (MARPs) in Brazil. Cad Saúde Pública 2011; 27 Suppl 1:S36-44.

17. Instituto Brasileiro de Geografia e Estatística. Censo demográfico de 2010. Características da população e dos domicílios: resultados do universo. http://www.ibge.gov.br/home/esta tistica/populacao/censo2010/caracteristicas_ da_populacao/default_caracteristicas_da_po pulacao.shtm 2010 (accessed on 15/Nov/2015).

18. Piscitelli A. On "gringos" and "natives": gender and sexuality in the context of international sex tourism in Fortaleza, Brazil. Vibrant (Brasília) 2004; 1:87-114.

19. Ministério da Saúde. Boletim Epidemiológico HIV/AIDS 2014; ano III, n. 1.

20. Brito AM, Castilho EA, Szwarcwald CL. Regional patterns of the temporal evolution of the aids epidemic in Brazil following the introduction of antiretroviral therapy. Braz J Infect Dis 2005; 9:9-19.

21. Ministério da Saúde. Pesquisa de conhecimentos, atitudes e práticas na população brasileira - PCAP 2008. Brasília: Departamento de DST, AIDS e Hepatites Virais, Secretaria de Vigilância em Saúde, Ministério da Saúde; 2011.

22. Associação Brasileira de Estudos Populacionais. Critério de classificação econômica Brasil. São Paulo: Associação Brasileira de Estudos Populacionais; 2008.

23. Babor T, Fuente J, Saunders J, Grant M. AUDIT - the alcohol use disorders identification test: guidelines for use in primary health care. Geneva: World Organization Health; 1992.

24. Lima CT, Freire AC, Silva AP, Teixeira RM, Farrell M, Prince M. Concurrent and construct validity of the audit in an urban Brazilian sample. Alcohol Alcohol 2005; 40:584-9.

25. Babor TF, Higgins-Biddle JC, Saunders JB, Monteiro MG. AUDIT - the alcohol use disorders identification test: guidelines for use in primary care. 2nd Ed. Geneva: World Health Organization; 2001.

26. Naimi TS, Brewer RD, Mokdad A, Denny C, Serdula MK, Marks JS. Binge drinking among US adults. JAMA 2003; 289:70-5.

27. Kuntsche E, Rehm J, Gmel G. Characteristics of binge drinkers in Europe. Soc Sci Med 2004; 59:113-27.

28. Plant MA, Plant ML. Binge Britain: alcohol and the national response. Oxford: Oxford University Press; 2006.

29. Laranjeira R, Pinsky I, Sanches M, Zaleski M, Caetano R. Alcohol use patterns among Brazilian adults. Rev Bras Psiquiatr 2010; 32:231-41. 
30. Wechsler H, Davenport A, Dowdall G, Moeykens B, Castillo S. Health and behavioral consequences of binge drinking in college: a national survey of students at 140 campuses. JAMA 1994; 272:1672-7.

31. Dimeff LA, Baer JS, Kivlahan DR, Marlatt GA. Alcoolismo entre estudantes universitários: uma abordagem de redução de danos. São Paulo: Editora Unesp; 2002.

32. Brewer RD, Swahn MH. Binge drinking and violence. JAMA 2005; 294:616-8.

33. Carlini EA. II levantamento domiciliar sobre o uso de drogas psicotrópicas no Brasil: estudo envolvendo as 108 maiores cidades do país, 2005. São Paulo: Centro Brasileiro de Informação sobre Drogas Psicotrópicas, Universidade Federal de São Paulo; 2006.

34. Maganja RK, Maman S, Groves A, Mbwambo JK. Skinning the goat and pulling the load: transactional sex among youth in Dar Es Salaam, Tanzania. AIDS Care 2007; 19:974-81.

35. Melendez RM, Pinto R. "It's really a hard life": love, gender and HIV risk among male-tofemale transgender persons. Cult Health Sex 2007; 9:233-45.

36. Belza MJ, Llácer A, Mora R, De La Fuente L, Castilla J, Noguer I, et al. Social characteristics and risk behaviors for HIV in a group of travesti and male transsexuals engaging in street prostitution. Gac Sanit 2000; 14:330-7.

37. Coan D, Schrager W, Packer T. The role of male sexual partners in HIV infection among male-to-female transgendered individuals. Int J Transgend 2005; 8:21-30.

38. Ghys PD, Jenkins C, Pisani E. HIV surveillance among female sex workers. AIDS 2001; 15 Suppl 3:S33-40.

39. Alexander P. Sex work and health: a question of safety in the workplace. J Am Med Womens Assoc 1998; 53:77-82.
40. Harcourt C, Donovan B. The many faces of sex work. Sex Transm Infect 2005; 81:201-6.

41. Vandepitte J, Lyerla R, Dallabetta G, Crabbé F, Alary M, Buvé A. Estimates of the number of female sex workers in different regions of the world. Sex Transm Infect 2006; 82 Suppl 3:iii18-25.

42. Vanwesenbeeck I. Another decade of social scientific work on sex work: a review of research 1990-2000. Annu Rev Sex Res 2001; 12:242-89.

43. Clements-Nolle K, Marx R, Guzman R, Katz M. HIV prevalence, risk behaviors, health care use, and mental health status of transgender persons: implications for public health intervention. Am J Public Health 2001; 91:915-21.

44. Nemoto T, Operario D, Keatley J, Han L, Soma T. HIV risk behaviors among male-to-female transgender persons of color in San Francisco. Am J Public Health 2004; 94:1193-9.

45. Bockting W, Kirk S. Transgender and HIV: risks, prevention and care. Binghamton: The Haworth Press; 2001.

46. Shankle M. The handbook of lesbian, gay, bisexual, and transgender public health: a practioner's guide to service. Binghamton: The Haworth Press; 2006.

47. Skinner WF. The prevalence and demographic predictors of illicit and licit drug use among lesbians and gay men. Am J Public Health 1994; 84:1307-10.

48. Bastos FI, Bertoni N, Hacker MA; Grupo de Estudos em População, Sexualidade e Aids. Consumo de álcool e drogas: principais achados de pesquisa de âmbito nacional, Brasil 2005. Rev Saúde Pública 2008; 42 Suppl 1:109-17. 


\section{Resumo}

Informação sobre uso de álcool entre mulheres transgêneros são escassas. Estimamos a prevalência do uso perigoso de álcool nos últimos 12 meses entre mulheres transgêneros chamadas travestis no Brasil, e identificados os fatores de risco associados. Trezentas travestis foram recrutadas utilizando Respondent Driving Sampling (RDS). Aplicamos o Alcohol Use Disorders Identification Test (AUDIT). Controlamos a amostragem, com um peso aplicado a cada entrevistada. Três quartos $(74,2 \%)$ das travestis eram bebedores regulares, metade $(48,7 \%)$ obteve $>8$ no AUDIT e $14,8 \%$ obtiveram $>20$. Fatores de risco para o uso de risco de álcool foram: > 24 anos, baixa renda, raça negra, viver com a família, ter feito sexo por dinheiro, uso de drogas ilícitas nos últimos seis meses e sexo desprotegido. O uso perigoso de álcool é prevalente entre travestis. Tendo em vista que este grupo possui maior risco para a infecção e transmissão de HIV, e que o uso perigoso de álcool foi associado ao sexo inseguro, são necessárias estratégias de intervenção específicas.

Consumo de Bebidas Alcoólicas; Pessoas

Transgênero; Travestismo

\section{Resumen}

Existe falta de información sobre el consumo de alcohol por parte de mujeres transexuales. El estudio estimó la prevalencia de consumo excesivo de alcohol durante los últimos 12 meses por parte de mujeres transexuales, conocidas en Brasil como travestis, e identificó los factores de riesgo. Fueron reclutadas 300 travestis, utilizando la técnica de Respondent Driven Sampling (RDS). Aplicamos el Alcohol Use Disorders Identification Test (AUDIT). La muestra fue controlada, aplicando un peso a cada entrevistada. Tres cuartos $(74,2 \%)$ de la muestra consumian alcohol regularmente, la mitad $(48,7 \%)$ totalizó más de ocho puntos en el AUDIT y 14,8\% sumaron más de 20 puntos. Los factores de riesgo para el consumo excesivo de alcohol fueron: edad por encima de 24 años, baja renta y sexo sin preservativo. El uso excesivo de alcohol es común entre las travestis. Debido a que el grupo presenta riesgo aumentado de transmisión del VIH, y que el uso excesivo de alcohol estuvo asociado al sexo inseguro, se necesitan estrategias específicas para mitigar los riesgos.

Consumo de Bebidas Alcohólicas; Personas Transgénero; Travestismo
Submitted on $24 / \mathrm{Jan} / 2015$

Final version resubmitted on 16/Nov/2015

Approved on 02/May/2016 